\title{
Reperfusão Rápida e Homogênea como Fator de Risco da Síndrome Pós-Reperfusão Hepática Durante Transplante Ortotópico de Fígado *
}

\author{
Rapid and Homogeneous Reperfusion as a Risk Factor for \\ Postreperfusion Syndrome during Orthotopic Liver Transplantation
}

\author{
Lucas Cordoví de Armas ${ }^{1}$, Rosa E. Jiménez Paneque ${ }^{2}$, Boris Gala López ${ }^{3}$, Edin Ismael Rápalo Romero ${ }^{4}$, \\ Ydriss Añuez Castillo ${ }^{5}$ e Marina Beatriz Vallongo Menéndez ${ }^{5}$
}

\section{RESUMO}

Cordoví de Armas L; Jiménez Paneque RE; Gala López B; Rápalo Romero El; Añuez Castillo Y; Vallongo Menéndez MB - Reperfusão Rápida e Homogênea como Fator de Risco da Síndrome Pós-Reperfusão Hepática Durante Transplante Ortotópico de Fígado.

JUSTIFICATIVA E OBJETIVOS: A revascularização do órgão transplantado é um momento crucial no transplante ortotópico de fígado (TOF). Aproximadamente um terço dos pacientes desenvolve síndrome pós-reperfusão hepática (SPR), uma combinação de hipotermia, desordens metabólicas e instabilidade cardiovascular que podem levar à parada cardíaca. O objetivo deste estudo foi avaliar a relação velocidade-qualidade (RVQ) da reperfusão do órgão transplantado como fator independente de predição da SPR.

MÉTODOS: Todos os pacientes elegíveis que se submeteram ao TOF em nossa instituição de 1987 a março de 2009 foram incluídos. O OR ajustado da associação RVQ-SPR foi obtido através do modelo de regressão logística, incluindo oito variáveis de confusão.

RESULTADOS: A proporção de pacientes que desenvolveram SPR foi maior nos pacientes com RVQ identificada como boa $(75,8 \%)$ do que naqueles com RVQ média ou baixa; o risco relativo ao comparar a RVQ de boa qualidade com a RVQ de baixa qualidade foi de 12,9 (IC 95\%: 2,1 - 528,8). O OR ajustado foi de 132,9 (IC 95\%: 10,5 $1688,6)$ quando a RVQ de boa e baixa qualidade foram comparadas e de 90,9 (IC 95\%: 13,8-645,2) comparando a RVQ boa com a intermediária.

\footnotetext{
* Recebido (Received from) do Hospital Clínico Quirúrgico Heramanos Ameijeiras, La Habana, Cuba.

1. Anestesiologista; Chefe do Serviço de Anestesiologia do Hospital Clínico Quirúrgico Heramanos Ameijeiras

2. Bioestatística

3. Cirurgião

4. Residente de Anestesiologia

5. Anestesiologista
}

Apresentado (Submitted) em 16 de outubro de 2008

Aceito (Accepted) para publicação em 24 de dezembro de 2009

Endereço para correspondência (Correspondence to):

Lucas Cordoví de Armas, MD, MsC

Hospital Hermanos Ameijeiras

M 18340. Monterrey. Habana 13100. Cuba

E-mail: lucas@infomed.sld.cu
CONCLUSÕES: De acordo com nossos resultados, a RVQ pode ser considerada um bom fator preditivo da SPR.

Unitermos: CIRURGIA, Transplante: fígado; FATORES DE RISCO; REPERFUSÃO

\section{SUMMARY}

Cordoví de Armas L; Jiménez Paneque RE; Gala López B; Rápalo Romero El; Añuez Castillo Y; Vallongo Menéndez MB - Rapid and Homogeneous Reperfusion as a Risk Factor for Postreperfusion Syndrome during Orthotopic Liver Transplantation.

BACKGROUND AND OBJECTIVES: The revascularization of the graft remains as a crucial instant of the orthotopic liver transplantation (OLT) surgical procedure. About a third of the recipients suffer the postreperfusion syndrome (PRS), a combination of hypothermia, metabolic disorders and cardiovascular instability potentially leading to cardiac arrest. The objective of this study was to evaluate the speed-quality (SQR) of the graft's reperfusion as an independent predictor of PRS.

METHODS: All eligible patients receiving an OLT in our institution from 1987 to march 2009 were included. The adjusted OR for SQRPRS association was obtained by means of logistic regression modeling including eight potential confounders.

RESULTS: The proportion of recipients suffering PRS was highest when the SQR was identified as good $(75.8 \%)$ compared to those with middle or poor SQR; the relative risk comparing good $S Q R$ with poor SQR was 12.9 (CI 95\%: 2.1-528.8). The adjusted OR was 132.9 (95\% Cl: 10.5-1688.6) when comparing good with bad SQR and 90.9 (95\% Cl: 13.8-645.2) when comparing good with intermediate $S Q R$.

CONCLUSIONS: According to our results, SQR can be considered an unambiguous predictor of PRS.

Keywords: SURGERY, Transplantation:liver; RISK FACTORS; REPERFUSION 


\section{Rapid and Homogeneous Reperfusion as a Risk Factor for Postreperfusion Syndrome during Orthotopic Liver Transplantation}

Lucas Cordovíde Armas, M.D.; Rosa E. Jiménez Paneque; Boris Gala López, M.D.; Edin Ismael Rápalo Romero, M.D.; Ydriss Añuez Castillo, M.D.; Marina Beatriz Vallongo Menéndez

\section{INTRODUCTION}

In spite of the progress achieved in all spheres linked to the orthotopic liver transplantation (OLT), the revascularization of the graft remains a crucial instant of the surgical intervention ${ }^{1,2}$.

Between eight and $30 \%$ of recipients suffer the so-called postreperfusion syndrome (PRS) ${ }^{3,4}$. This syndrome is characterized by a combination of hypothermia, metabolic disorders and cardiovascular instability. Thus, if PRS is not foreseen and treated, it can even drive the patient to a cardiac arrest ${ }^{5-6}$.

The actions executed by the anesthesiologist have been standardized with the aim of facing five distinctive components of the PRS 6-8: acidemia, hyperkalemia, ionic hypocalcemia, heart depression and vasoplegia, which may occur in sequence during the blood flow through the grafted liver. But the PRS does not come about in all OLT's with same severity neither has been invoked a way to predict its occurrence. Thus, it is not discarded that maneuvers (intravenous administration of calcium, bicarbonate and possibly adrenaline) that so far have characterized its prevention could also entail serious consequences ${ }^{9}$. It is therefore understood the importance of clinical indicators which not only could contribute to prevent PRS's onset but to perform its treatment adjusted to the necessities of each recipient.

Ever since the first experiences obtained by the authors of this study in 1987 a suspicion arose that the greater the speed and uniformity of the reperfusion of the donor liver, the higher the frequency PRS may occur.

Some studies report the use of devices for measuring blood flow through the liver but they all evaluate the relation between quantitative aspects of the flow post-reperfusion and the organ function or their impact on the ischemia-reperfusion injury, both in the medium term 10-12.

The study of possible associations between the flow levels measured during reperfusion and the incidence of the PRS is not reported strongly. In a single retrospective study reported by Nanashima et al., portal venous and hepatic arterial flow rates measurements did not show any association with PRS occurrence but authors only give details about the device employed by omitting the chronologic particulars of these instrumentations so they did not explain the time elapsed between the beginning of revascularization and flow rate measurements ${ }^{13}$.

We hypothesized that if the revascularization of the liver happens immediate and homogeneously the irruption of mediators into the blood circulation would reach high concentrations in only few seconds leading to serious cardiovascular consequences. The aim of the present study was to demonstrate this hypothesis.

\section{METHODS}

The surgical unit of the institution where this research was carried out has 14 operating rooms, and more than 1500 surgical procedures yearly are conducted there. Among these are the OLT's of which 138 have been carried out from 1987 to date. All patients receiving an OLT were included in the study provided they met the following inclusion criteria: hepatic cirrhosis with a Child-Pugh score over nine points, age between 18 and 60 years, no lung hypertension or serum creatinine over $1.5 \mathrm{mg} . \mathrm{dL}^{-1}$. The donor must have been under 80 years of age and could not be supported with alpha-agonist agents, nor be in cardiac death. The donor liver must have been free of steatosis signs and total time of ischemia under eight hours. The surgical technique must have been hepatectomy with cava vein preservation (Piggyback) with or without temporary portocaval shunt (PCS); preservation solution must have been University of Wisconsin (UW) [DuPont, Bad Homburg, Germany], Celsior [SangStat. Lyon, France] or histidine-tryptophan-ketoglutarate (HTK) [Dr. Kohler Chemie $\mathrm{GmbH}$. Alsbach, Germany].

We excluded recipients with contraindications for aprotinine administration and those which in the moment of the reperfusion exhibited for any reason a cardiac index decrease $>20 \%$ of the one registered one hour after beginning the surgical procedure. Briefly, we excluded those reperfusions influenced by a deteriorated general hemodynamic. Retrasplants and OLT combined with other organ transplants were excluded as well. Patients with mean arterial pressure, recorded one hour after beginning the surgical intervention, under $30 \%$ of the baseline for at least 1 minute following the onset of the circulation through the porta 
and cava veins, were considered as having a PRS.

The principles of this definition were uttered in 1987 and it has been used later on in other works ${ }^{3,5,7}$. The fact that OLT's require more than one surgeon, allows a multiple visual evaluation of what we have called reperfusion's speed-quality (SQR), the main predictor considered herein. For the definition of this variable we took into account 2 criteria: 1) chronological criterion: quick reperfusion, if it begins in 30 seconds or less after unclamping vena porta and receiving the surgeons simultaneous warning. It was measured with a chronometer by the anesthesiologist himself who observed and registered the data, and 2) qualitative criterion; homogeneous reperfusion, if the whole surface of the grafted liver changes its pale gray-rosy color (due to the blood exclusion caused by the retrieval process, perfusion and conservation) to a red-violet color, shining and uniform, typical of the venous hyperemia. The latter criterion assessment was done by each of the surgeons who, immediately after the operation, answered the following question on a printed form: "Do you consider the reperfusion took place in a satisfactorily homogeneous way?" Yes / No. Express your personal opinion.

The authors determined that the reperfusion could be deemed as good $(G)$ if both criteria were achieved, middle $(M)$ if only one of both criteria was achieved and poor $(P)$ if none of both criteria was achieved. Between 2 and 4 surgeons participated in each operation, thus, if there was no agreement regarding homogeneity of the reperfusion it was considered as middle. We considered the donors age, ICU length of stay of donor (in hours), recipient's age, sex and Child-Pugh score, preservation solution used, use or not of PCS, and total ischemia time as potential confounders.

Univariate association between categorical variables, including SQR, and the onset of PRS was assessed with Chi square test. The relative risk (RR) of PRS was also estimated with 95\% confidence interval. For quantitative predictors we used Student's $t$ test for comparing means between those who had
PRS with those who did not. The OR of SQR-PRS association adjusted for the potential confounders was obtained by means of the logistic regression model. The variables were included in two blocks, confounders in one block and the main predictor in the other. Data were processed with SPSS v. 11.5.1. (SPSS Inc., Chicago, IL)

All information related with the identity of the patients and of the surgeons was omitted in the analysis of the data, thus, it was not necessary to obtain the informed consent of the patients for research purposes. The project was approved by the Scientific Commission and the Research Ethics Committee of the Institution. All the transplants carried out in the institution require the patients sign a written informed consent.

\section{RESULTS}

Table I displays the results of the univariate statistical analysis looking for an association between the studied categorical variables and the occurrence or not of the PRS, especially SQR. No significant associations were found between the onset of PRS and the sex of the recipient, the realization of PCS or the type of preservation solution. The proportion of recipients suffering PRS was highest when the SQR was identified as good (75.8\%) compared to those with middle or poor SQR; the relative risk comparing good SQR with poor SQR was 12.9 (IC 95\%: 2.1-528.8). No significant differences were found between means of quantitative variables in those with and without PRS (Table II). When including all potential confounders in a logistic regression model (Table III), only SQR showed significant independent association with the onset of PRS. The adjusted OR was 132.9 (95\% Cl: 10.5-1688.6) when comparing good with bad SQR; 90.9 (95\% Cl: 13.8-645.2) when comparing good with intermediate SQR. Adjusted OR comparing intermediate with bad SQR was not significant (1.4 95\% Cl: 0.1-14.6 N.S.).

Table I - Onset of Postreperfusion Syndrome and Relative Risk According to Levels of Categorical Variables

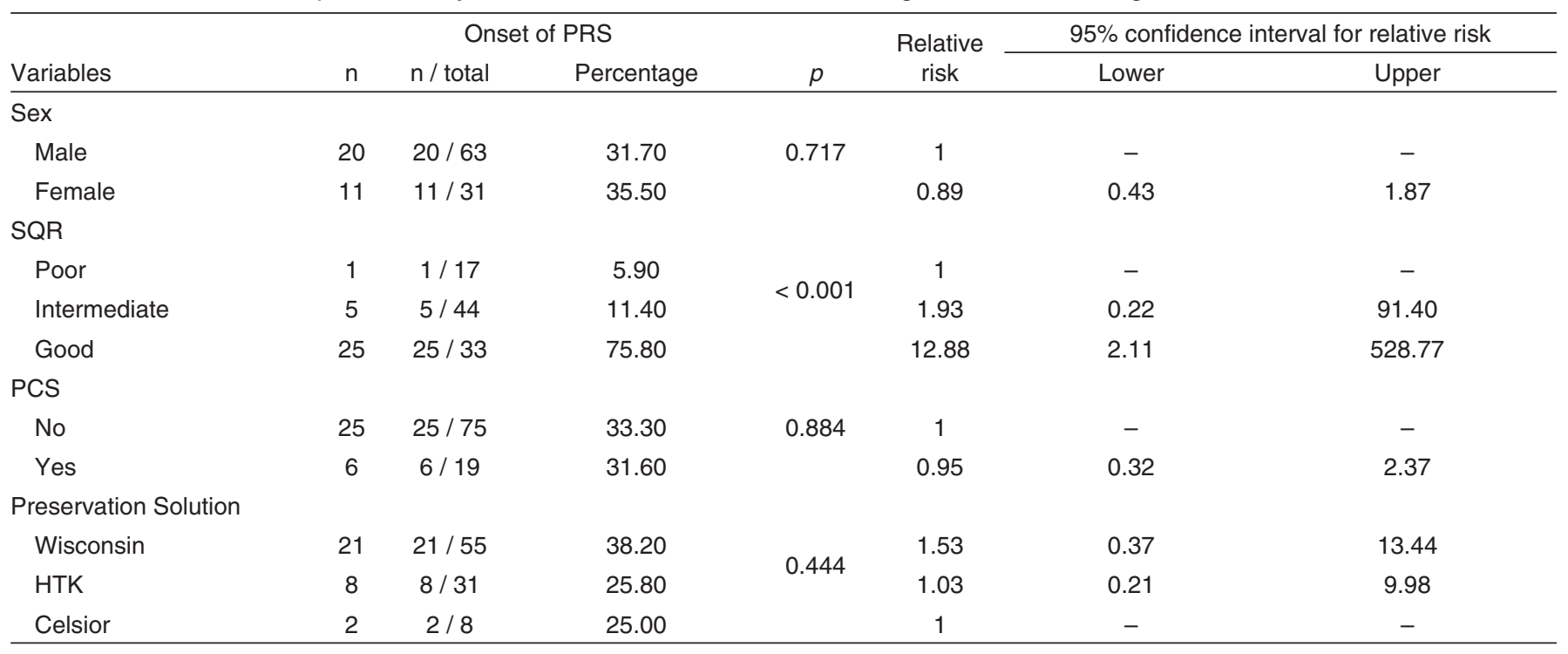

SQR - Speed-quality of reperfusion; PCS - Temporary porto-cava shunt; HTK - Histidine-tryptophan-ketoglutarate 
Table II - Mean and Standard Deviation for Quantitative Variables According to Onset of Postreperfusion Syndrome.

\begin{tabular}{|c|c|c|c|c|c|c|c|}
\hline \multirow{2}{*}{ Variables } & \multicolumn{2}{|c|}{ PRS No } & \multicolumn{2}{|c|}{ PRS Yes } & \multicolumn{2}{|c|}{ Total } & \multirow[b]{2}{*}{$p^{a}$} \\
\hline & Mean & SD & Mean & SD & Mean & SD & \\
\hline Donor age (years) & 34.94 & 10.99 & 37.35 & 12.58 & 35.73 & 11.53 & 0.342 \\
\hline Total ischemia time (hs) & 6.73 & 0.74 & 6.75 & 0.85 & 6.74 & 0.78 & 0.930 \\
\hline Recipient age (years) & 45.11 & 8.74 & 41.90 & 11.39 & 44.05 & 9.75 & 0.135 \\
\hline Child-Pugh score & 11.25 & 1.71 & 11.42 & 1.31 & 11.31 & 1.59 & 0.637 \\
\hline
\end{tabular}

a Student $t$ test

Table III - Logistic Regression Results

\begin{tabular}{|c|c|c|c|c|c|c|}
\hline \multirow[b]{2}{*}{ Variables $^{\text {a }}$} & \multirow{2}{*}{$\begin{array}{c}\text { Regression } \\
\text { coefficient }\end{array}$} & \multirow[b]{2}{*}{ SE } & \multirow[b]{2}{*}{$p$} & \multirow{2}{*}{$\begin{array}{l}\text { Adjusted } \\
\text { odds ratio }\end{array}$} & \multicolumn{2}{|c|}{$95 \% \mathrm{Cl}$ for adjusted odds ration } \\
\hline & & & & & Lower & Upper \\
\hline Recipient gender & 1.14 & 0.77 & 0.14 & 3.11 & 0.68 & 14.18 \\
\hline Child-Pugh score & -0.15 & 0.25 & 0.53 & 0.86 & 0.53 & 1.39 \\
\hline Total ischemia time & -0.15 & 0.45 & 0.73 & 0.86 & 0.35 & 2.09 \\
\hline Donor age & 0.06 & 0.04 & 0.10 & 1.06 & 0.99 & 1.14 \\
\hline PCS performance & -1.08 & 0.86 & 0.21 & 0.34 & 0.06 & 1.83 \\
\hline Preservation solution ${ }^{\mathrm{b}}$ & & & 0.08 & & & \\
\hline Preservation solution (Wisconsin) & 2.91 & 1.39 & 0.04 & 18.30 & 1.21 & 276.90 \\
\hline Preservation solution (HTK) & 1.73 & 1.32 & 0.19 & 5.63 & 0.43 & 74.44 \\
\hline $\mathrm{SQR}^{\mathrm{c}}$ & & & 0.00 & & & \\
\hline
\end{tabular}

a. Variables included in two blocks: Block 1: all potential confounders; Block 2: SQR (Speed-quality of reperfusion)

b. Dummy for preservation solution: reference Celsior. Adjusted OR Wisconsin/HTK $=3.25(p=0.134)$

c. Dummy for SQR: reference (bad quality). Adjusted OR good/intermediate $=94.54)(95 \% \mathrm{Cl}: 13.85-645.16)(p=0.002)$

\section{DISCUSSION}

There are not consistent researches to identify a potential association between the reperfusion speed-quality of the liver grafted and the onset of PRS.

Some studies have been designed with the goal of finding predictors of the graft future function or other conditions associated to the tissue damage emerging from the ischemia-reperfusion injury and its further influence in the rejection phenomena as well as in the immune-suppression therapy decisions in the medium term 10-12,14. These studies were not meant to identify a relationship between the trans-visceral flow and the occurrence of PRS as a possible intra-operative event.

In an effort to compensate the technical limitation of not using flow-measuring devices which could objectively assess the SQR, we have chosen an evaluation made by the acting surgeons who ignored the purpose of the posed question. It is not discarded that this "humanized" form of evaluating the SQR could even be better than some devices which can only measure blood flow and not homogeneity.

The anatomical and functional distortions observed in the vascular bed of the patient with liver cirrhosis and advanced hepatic failure, propitiate a particular phenomenon described in a recent work: in some patients the portal flow after the OLT may remain insufficient due to the existence of a number of collateral portosystemic shunts with enough caliber to divert the graft's portal flow ${ }^{12}$. This circulatory condition would explain by itself a wide range of the portal flow intensities at the moment of the reperfusion together with a variety of chemical and hemodynamic responses. The existence of a variety of portosystemic outflows explains, at least partially, the association between the SQR and the PRS onset. Provided the portal flow is not damaged, better SQR could be obtained together with a high probability of the onset of PRS.

The virtual absence of published studies assessing this probable association could be explained with at least two lines of reasoning: 1) the PRS is a sudden and potentially lethal complication whose complexity hinders the use of devices that could obstruct emergent actions possibly needed in those circumstances, 2) it is difficult to design prospective studies with an appropriate number of groups and variables. In a study published in 2003 including more than 180 OLT, 34 variables with potential association to the PRS are involved. ${ }^{8}$ None of them accounted for the quality or speed of reperfusion.

The hypothesis enunciated here connotes an analogy between 
the blood emerging from the graft and any drug or agent whose quick intravenous injection could cause unexpectedly high plasma concentrations with deleterious effects for the cardiovascular system. If PRS is an entity originated by the chemical nature (electrolytes, as potassium hydrogen-ions or other substances derived from the ischemic injury, or a combination of all them), and the low temperature of the blood coming from the liver and the congestive bowel, then the notion that a high flow could constitute a risk factor for the onset of this manifestation is plausible. A homogeneous and briefly launched reperfusion (good SQR) as suggested by the results of this study, should be considered an important risk factor for the PRS. The wide confidence interval obtained for the adjusted odds ratio reflects imprecision caused by the relatively small number of studied cases but leaves no doubt about the existence of such association.

An important reason for this reduced number of OLT is that before 2001 we had a protocol with more rigid criteria for donor selection, for example, less than 51 years old, no support with alpha-agonist drugs, PEEP below three $\mathrm{cm} \mathrm{H}_{2} \mathrm{O}$, no evidence of liver steatosis, no cardiac arrest history and others. The results of the present study lead to two practical suggestions: first; the anesthesiologist would have to share his attention between the screens of the monitors and a strict observance of the speed-quality of the reperfusion taking place and with these integrated information regulate the rate with which he/she performs usual administrations of drugs to neutralize the effects of the blood coming from the portal bed whose degree of cellular integrity is unknown; second; it would be necessary to evaluate the convenience of practicing the arterial revascularization in the first place allowing the reperfusion to take place with less speed and more oxygen content. The latter alternative is opposed to the results of a study in 2006 where it is concluded that this variant offers advantages only for the recipients with a limited functional capacity due to a limited myocardial contractility ${ }^{16}$.

Future prospective designs, with more patients and the use of some device to measure blood flow through the suprahepatic vena cava, could contribute to confirm the results of the present study.

\section{REFERÊNCIAS - REFERENCES}

01. Hoffmann K, Weigand MA, Hillebrand $\mathrm{N}$ et al - Is veno-venous bypass still needed during liver transplantation? A review of the literature. Clin Transplant, 2009;23:1-8.

02. Hilmi I, Horton CN, Planinsic RM et al - The impact of postreperfusion syndrome on short-term patient and liver allograft outcome in patients undergoing orthotopic liver transplantation. Liver Transpl, 2008;14:504-508.

03. Aggarwal S, Kang Y, Freeman JA et al. - Postreperfusion syndrome: cardiovascular collapse following hepatic reperfusion during liver transplantation. Transplant Proc, 1987;19(4 Suppl 3):54-55.

04. Ulukaya S, Basturk B, Kılıç M et al. - Cytokine gene polymorphism and postreperfusion syndrome during orthotopic liver transplantation. Transplant Proc, 2008; 40:1290¹293.

05. Shi XY, Xu ZD, Xu HT et al. - Cardiac arrest after graft reperfusion during liver transplantation. Hepatobiliary Pancreat Dis Int, 2006;5:185-189.

06. Ulukaya S, Alper I, Aydin U et al. - Successful resuscitation of cardiac arrest due to postreperfusion syndrome during orthotopic liver trans- plantation: a case report. Transplant Proc, 2007;39:3527³529.

07. Ayanoglu HO, Ulukaya S, Tokat $Y$ - Causes of postreperfusion syndrome in living or cadaveric donor liver transplantations. Transplant Proc, 2003;35:1442-1444.

08. Tsinari KK, Misiakos EP, Lawand CT et al. - Factors affecting metabolic and electrolyte changes after reperfusion in liver transplantation. Transplant Proc, 2004;36:3051-3056.

09. American Heart Association guidelines for cardiopulmonary resuscitation and emergency cardiovascular care. Part 10.1: Life-threatening electrolyte abnormalities. Circulation, 2005;112(24/Suppl):IV-121-125.

10. Puhl G, Schaser KD, Vollmar B et al. - Non-invasive in vivo analysis of the human hepatic microcirculation using orthogonal polarization spectral (OPS) imaging. Transplantation, 2003;75:756-761.

11. Lisik W, Gontarczyk G, Kosieradzki M et al. - Intraoperative blood flow measurements in organ allografts can predict postoperative function. Transplant Proc, 2007;39:371-372.

12. Aucejo FN, Hashimoto K, Quintini C et al. - Triple-phase computed tomography and intraoperative flow measurements improve the management of portosystemic shunts during liver transplantation. Liver Transpl, 2008;14:96-99

13. Nanashima A, Pillay $P$, Crawford $M$ et al. - Analysis of postrevascularization syndrome after orthotopic liver transplantation: the experience of an Australian liver transplantation center. J Hepatobiliary Pancreat Surg, 2001;8:557-563.

14. Puhl G, Schaser KD, Pust D et al. - Initial hepatic microcirculation correlates with early graft function in human orthotopic liver transplantation. Liver Transpl, 2005;11:555-563.

15. Mizunuma $\mathrm{K}$, Ohdan $\mathrm{H}$, Tashiro $\mathrm{H}$ et al. - Prevention of ischemia-reperfusion-induced hepatic microcirculatory disruption by inhibiting stellate cell contraction using rock inhibitor. Transplantation, 2003;75:579-586.

16. Moreno C, Sabaté A, Figueras J et al. - Hemodynamic profile and tissular oxygenation in orthotopic liver transplantation: influence of hepatic artery or portal vein revascularization of the graft. Liver Transpl, 2006;12:1607-1614.

\section{RESUMEN}

Cordoví de Armas L; Jiménez Paneque RE; Gala López B; Rápalo Romero El; Añuez Castillo Y; Vallongo Menéndez MB - Reperfusión Rápida Y Homogénea Como Factor De Riesgo Del Síndrome PostReperfusión Hepática Durante Transplante Ortotópico De Hígado.

JUSTIFICATIVA Y OBJETIVOS: La revascularización del órgano transplantado es un momento crucial en el transplante ortotópico de hígado (TOH). Aproximadamente un tercio de los pacientes debuta con síndrome de post-reperfusión hepática (SPR), una combinación de hipotermia, desórdenes metabólicos e inestabilidad cardiovascular que pueden conllevar a la parada cardíaca. El objetivo de este estudio fue evaluar la relación velocidad-calidad ( $R V C$ ), de la reperfusión del órgano transplantado como factor independiente de predicción de la SPR.

MÉTODOS: Todos los pacientes elegibles que se sometieron al TOH en nuestra institución desde 1987 a marzo de 2009, estuvieron incluidos en el estudio. El OR ajustado de la asociación RVC-SPR, se obtuvo a través del modelo de regresión logística, incluyendo ocho variables de confusión.

RESULTADOS: La proporción de pacientes que debutaron con SPR fue más elevada en los pacientes con RVC identificada como buena $(75,8 \%)$, que en aquellos con RVC media o baja; el riesgo relativo al comparar la RVC de buena calidad con la RVC de baja calidad fue de 12,9 (IC 95\%: 2,1 -528,8). El OR ajustado fue de 132,9 (IC 95\%: 10,5-1688,6) cuando la RVC de buena y baja calidad fueron comparadas, y de 90,9 (IC 95\%: 13,8-645,2) comparando la RVC buena con la intermedia.

CONCLUSIONES: De acuerdo con nuestros resultados, la RVC puede ser considerada como un buen factor predictivo de la SPR. 